\title{
SEROLOGICAL SCREENING FOR CELIAC DISEASE IN SYMPTOMATIC 12 TO 36 MONTH-OLD CHILDREN
}

\author{
Inês Cristina MODELLI ${ }^{1,2}$, Lenora GANDOLF ${ }^{2,3}$, Rodrigo Coutinho de ALMEIDA ${ }^{3}$, \\ Gloria Maria A. C. ARAÚJO², Marilúcia de Almeida PICANÇO² and Riccardo PRATESI ${ }^{2}, 3$
}

\begin{abstract}
Context - The correct diagnosis of celiac disease in environmentally deprived children is frequently hindered by the common presence of other causes for the classical celiac disease symptoms: malnutrition, failure to thrive and frequent diarrheas. Objectives - To determine the prevalence of celiac disease in a group of 12 to 36 month-old children using immunoglobulin antibodies against gliadin (IgG and IgA-AGA), against endomysium (IgA-EMA), and against human tissue transglutaminase (IgA-tTG) as screening method. Methods - A total of 214 children (114 boys), aged 12 to 36 months, on gluten-containing diet, were admitted to the study. IgG and IgA-AGA, IgA-tTG and IgA-EMA tests were performed in all sera. Biopsy was obtained from all children showing positive result in one or more of the serologic tests, excluding those in which IgG-AGA had been the only positive result. In those cases, polymerase chain reaction (PCR) HLA genotyping for the identification of celiac disease predisposing alleles was applied. HLA genotyping was also performed to confirm the diagnosis in children identified as celiac by means of positive serologic testing and compatible biopsy results. Results - Normal results were obtained in 131 children. Ten children out of 68 identified as positive exclusively on the IgG-AGA test disclosed the presence of celiac disease predisposing alleles on PCR and underwent jejunal biopsy with normal results. All serologic tests were positive in four children. A fifth child showed positive IgG and IgA-AGA and IgA-tTG results but disclosed a negative IgA-EMA test. Jejunal biopsy of these five children revealed characteristic lesions of celiac disease. Conclusion - A prevalence of $2.3 \%$ was found among symptomatic 12- to 36-month-old children that had not been previously diagnosed as celiac.
\end{abstract}

HEADINGS - Celiac disease, diagnosis. Serologic tests. Child.

\section{INTRODUCTION}

Celiac disease (CD) is a common multifactorial, immuno-mediated enteropathy triggered by the ingestion of several related proteins found in wheat (gliadin), barley (hordein), and rye (secalin). In genetically susceptible individuals the ingestions of these proteins leads to infiltration of the intestinal mucosa by both intraepithelial CD8+ and lamina propria CD4+ lymphocytes that ultimately result in a variable degree of jejunal tract lesion ${ }^{(31)}$.

$\mathrm{CD}$ has one of the strongest HLA associations. The presence of HLA-DQA $1 * 05$ and DQB $1 * 02$ alleles, either in cis or in trans, which form the HLA-DQ2 heterodimer, strongly increases the risk for CD. In European white population, approximately $90 \%$ of $\mathrm{CD}$ patients have these genetic markers whereas most of the remaining cases carry HLA-DQ8 molecules coded by the HLA-DQA $1 * 03$ and DQB $1 * 0302^{(19)}$. The value of HLA typing in CD is mainly considered for its negative predictive value since $C D$ does not develop unless a person carries alleles that encode for HLA-DQ2 or DQ8 ${ }^{(15)}$.

CD symptomatology is variable and in its classical presentation, mostly seen in children, malabsorption of nutrients leads progressively to severe malnutrition, failure to thrive and diarrheic stools. In adults the clinical manifestations of CD are often oligosymptomatic or atypical, characterized by abdominal pain, bloating, frequents bouts of aftous stomatitis, resistant anemia or by an ill defined physical and emotional distress ${ }^{(14)}$. This changeable clinical picture, frequently results in a delayed diagnosis. Adolescent and young adults are, in many instances, free of major symptoms being eventually diagnosed during screening studies. The timing for the appearance of the first symptoms is variable and probably not only related to the gluten content of the diet but also to other still unknown environmental triggers ${ }^{(7)}$.

$\mathrm{CD}$ was originally thought to occur only rarely and predominantly in childhood but during the last few decades, with the advent of reliable serological testing

${ }^{1}$ Graduate Program in Health Sciences, University of Brasilia School of Health Sciences; ${ }^{2}$ Pediatric Department, Brasilia University Hospital, University of Brasilia School of Medicine; ${ }^{3}$ Pediatric Research Center and Celiac Disease Investigation Center, University of Brasilia School of Medicine, Brasilia, DF, Brazil

Correspondence: Dr. Riccardo Pratesi - SQN 212 - Bloco F - apt.605 - 70864-060 - Brasília, DF, Brazil. E-mail: pratesir@unb.br / pratesir@gmail.com 
that allowed large screening studies, a steady worldwide increase in its prevalence was noted. Currently CD is recognized as a global health problem. Its estimated prevalence in Europe and United States has varied from 1:100 to 1:250 both in children $^{(5,17)}$ and in adults ${ }^{(6)}$, and values as high as 1:99 were found in children aged 14 to 21 years in Finland ${ }^{(20)}$. Several screening studies carried out during the last decade in Brazil show a prevalence similar to that found in European countries, varying from $1: 213$ to $1: 681$ in presumably healthy blood donors $^{(12,22,23)}$ while other screening studies carried out in different Brazilian regions showed frequencies ranging from $1: 53$ to $1: 417^{(11,24,32)}$.

The aim of this study was primarily to determine the prevalence of CD in a group of 12-to 36-month-old symptomatic children using antibodies against gliadin, endomysium, and recombinant human tissue transglutaminase as screening method and, secondarily to call the attention to the difficulties in correctly diagnosing CD among socio-economically and environmentally deprived children.

\section{METHODS}

This project was approved by the Ethics Committee of the University of Brasilia School of Health Sciences, Brasilia, DF, Brazil (protocol 051/2003). Children's parents were invited to participate in the study and received written and verbal information regarding the objectives, risks, and benefits of the study. Children aged 12- to 36-months who attended the Pediatric Gastroenterology Unit of the Brasilia University Hospital between August 2004 and February 2007, and were considered at risk for CD were included in the study. The Brasilia University Hospital is a general hospital, part of the unified government health system that attends mainly low-income population living in the periphery of the city. Although this population cannot be considered deeply disadvantaged by Brazilian standards, the prevalence of malnutrition, parasitosis, and infectious diseases is still considered high among them, especially during the first 3 years of life.

Two hundred and fourteen children were admitted to the study (114 boys). The age of admission varied from 12 to 36 months (mean and median, 19 months). One hundred seventy seven $(82.7 \%)$ were less than 24 and $37(17.3 \%)$ were less than 36 months-old. All children had been on gluten-containing diet for at least the previous 6 months. The children were considered at risk for CD and included in the study when their parents reported: 1) history of episodes of persistent diarrhea (defined as an increase in frequency and liquidity of stools above the norm for the child, for a period of 2 or more weeks); and b) height or weight below the 5 th percentile.

Serum samples were collected from each participant and stored at $-20^{\circ} \mathrm{C}$ until testing. Total immunoglobulin A (IgA) level was determined in all sera by turbidimetric immunoquantification (COBAS MIRA; Roche Diagnostic Systems, Basel, Switzerland). Enzyme-linked immunosorbent assay technique (ELISA) was applied to all sera to determine
IgG and IgA antigliadin (IgG-AGA, IgA-AGA) and IgA antitransglutaminase (IgA-tTG) antibody values (Quanta Lite IgG and IgA Gliadin and IgA Transglutaminase, INOVA Diagnostic Inc., San Diego, CA, USA). The antibody concentrations were expressed in arbitrary units (AU), that is, percentages of the positive reference serum, and values $\geq 20$ AU were considered positive.

Serum IgA-class endomysial antibodies (IgA-EMA) were determined by indirect immunofluorescence method. Briefly, 4- $\mu \mathrm{m}$ cryostat sections from the distal portion of monkey esophagus (INOVA Diagnostic Inc., San Diego, CA) were incubated with patients' sera at a 1:5 dilution. The reaction was detected with fluorescein isothiocyanate rabbit antihuman IgA conjugate applied to the sections. Under the fluorescence microscope, the presence of characteristic honeycomb-like brilliant green pattern of smooth muscle bundles was interpreted as positive. Children who showed positive result in any test underwent repeated testing for confirmation of the results.

Small bowel biopsy was suggested to parents of children who showed positive results in one or more of the IgA-AGA, IgA-EMA and IgA-tTG serologic tests, and in those children in whom the only positive test was IgG-AGA but were carriers of CD predisposing HLA alleles. The aim of this procedure was to avoid unnecessary biopsies in view of the low specificity of the IgG-AGA and the strong negative predictive value of the absence of HLA predisposing alleles ${ }^{(15)}$. Genomic DNA was extracted from peripheral venous blood using the Illustra Blood Genomic Prep Mini Spin Kit (GE Healthcare, UK). Genotyping for HLA-DQA1*0501, HLA-DQB1*0201 and DRB1*04 was processed by the technique of polymerase chain reaction-sequence specific primers (PCR-SSP) as previously described ${ }^{(27)}$.

Biopsies were performed with a Watson pediatric capsule, samples being taken at the level of the ligament of Treitz. Biopsy specimens were independently evaluated by a pathologist and a pediatric gastroenterologist and assessed according to the scoring system described by Marsh ${ }^{(21)}$.

\section{RESULTS}

All the 214 children included in the study had normal IgA serum levels. Normal results were obtained in all serological tests (IgG/IgA-AGA, IgA-EMA and IgA-tTG) in 131 children (61.2\%). The PCR-SSP of the 68 children whose serologic tests results only showed increased level of IgG-AGA disclosed the presence of a predisposing allel in 10. Their jejunal biopsies together with those of the 10 children that had shown increased levels of both IgG and IgA-AGA with normal results on IgA-EMA and IgA-tTG testing, disclosed a normal mucosal structure (Marsh 0). Positive IgA-EMA test and increased levels of IgG-AGA, IgA-AGA and IgAtTG antibodies were found in four children. A fifth child, a 20-month-old boy, showed abnormal IgG, IgA-AGA and IgA-tTG tests but disclosed a negative immunofluorescent IgA-EMA. Immunologic and clinical findings in children positive on serologic testing can be seen in Table 1 . 
TABLE 1. Clinical data, serologic tests and biopsy results of the five celiac children

\begin{tabular}{|c|c|c|c|c|c|c|c|c|}
\hline & Sex & $\begin{array}{c}\text { Age } \\
\text { (months) }\end{array}$ & Symptoms & IgG-AGA & $\operatorname{IgA-AGA}$ & IgA-tTG & IgA-EMA & Biopsy \\
\hline 1 & $\mathrm{~F}$ & 17 & Diarrhea, bloating, malnutrition & 118.1 & 196.8 & 242.7 & + & Marsh III \\
\hline 2 & M & 20 & Diarrhea, anemia, bloating, malnutrition & 142.7 & 226.2 & 85.6 & _ & Marsh III \\
\hline 3 & $\mathrm{~F}$ & 26 & Diarrhea, RAP, anemia, bloating, malnutrition & 86.9 & 193.4 & 215.4 & + & Marsh III \\
\hline 4 & $\mathrm{~F}$ & 32 & Diarrhea, malnutrition & 42.7 & 99.9 & 52.9 & + & Marsh III \\
\hline 5 & $\mathrm{~F}$ & 35 & Fatigue, anemia, bloating, malnutrition & 105.5 & 61 & 127.3 & + & Marsh III \\
\hline
\end{tabular}

Jejunal biopsy of the five serologic positive children disclosed mucosal lesions characterized by a villous flattening, crypt hypertrophy and increased number of intraepithelial lymphocytes characterizing a CD enteropathy (Marsh III). The prevalence of serological and biopsy confirmed cases of $\mathrm{CD}$ in the present cohort was 1:43 (2.3\%).

\section{DISCUSSION}

Among the symptomatic children screened in the present study we found a CD prevalence of 5:214 (2.3\%). Despite the presence of chronic diarrhea, failure to thrive and signs of malnutrition, none of these 214 children had been previously diagnosed as celiac or had undergone serologic testing to rule out the possibility of $\mathrm{CD}$. A disturbing question raised by the present findings is how many celiac children, belonging to underprivileged segments of society, with varying degrees of chronic gastrointestinal symptoms and malnutrition have their diagnosis postponed or worse, could die wrongly diagnosed as carrier of environmental enteropathy. This cannot be considered an improbable hypothesis as suggested by a previous study in which an unexplained age-related variation on $\mathrm{CD}$ prevalence with a clustering of most cases of $\mathrm{CD}$ in the younger age group was detected ${ }^{(26)}$. An increased prevalence of CD in children when compared to adults is an unexpected fact since it is known that CD may start at any age, and being a disorder for life, would be expected to have a higher prevalence among adults. This difference in prevalence between children and adults had already been observed by other authors ${ }^{(10,33)}$. A possible explanation for this fact could be that children, especially those born in an adverse environment and exposed to a high level of infectious and parasitic agents die as a result of early complications without reaching adulthood. The mortality rate among undiagnosed symptomatic celiac children on a diet containing gluten can be high. Hardwick ${ }^{(16)}$ in a pioneer 15 -years follow-up study with 70 celiac children, published in 1939, reported an overall mortality rate of $36 \%$. In the same study this author perceptively observed that although there was no difference in the number of $\mathrm{CD}$ cases between breast-fed and bottle-fed infants, none of the very young celiac patients had been breast-fed. Presently, several studies are focused on the deleterious consequences of an early introduction of gluten in the infant diet and the protective effect of breast-feeding ${ }^{(2,18,25)}$. Evidences suggest that both breast-feeding during the introduction of dietary gluten, and increased duration of breast-feeding are associated with reduced risk for the development of CD although it is still not clear whether breast-feeding delays the onset of symptoms or provides a permanent protection against the disease ${ }^{(1)}$. The increasing participation of women as workforce in Brazil frequently results in an early introduction of inappropriate amount and often unfit complementary food and a shorter breast-feeding period ${ }^{(8,18)}$.

Even when suspected, to confirm a definitive $\mathrm{CD}$ diagnosis in these environmentally deprived children is not an easy task. Besides their poor nutritional status, frequently associated with infections and parasitosis, these children can also be affected by allergic or even autoimmune disorders resulting in clinical conditions that can be indistinguishable from the classical presentation of $C D$ in this age group ${ }^{(13)}$. Patient number 2 (Table 1) is a good example of the difficulty in properly diagnosing $\mathrm{CD}$ in children subjected to multiple adverse environmental factors. This patient was, when initially seen, severely malnourished and had a history of persistent diarrhea, repetitive bouts of respiratory infections and probable cow's milk intolerance. As shown in Table 1, the child's IgA-EMA was initially tested at the age of 20 months, being negative at that time. The child underwent a slow recovery on a gluten and milk-free diet. When he was 3 years-old, asymptomatic and with weight within normal range for age, to definitively establish the diagnosis of $\mathrm{CD}$, a gluten challenge was started and serologic tests were repeated after 1 more year of normal diet disclosing, at that time, positive IgA-EMA and IgA-tTG (101.3U). The diagnosis of CD was confirmed and the child was again started on gluten free diet (GFD). It is known that in this age group, high levels of antibodies against tTG can be present and fluctuate even in non-celiac children ${ }^{(29,}$ 30). In addition, false positive tTG tests have been eventually observed in other inflammatory and autoimmune diseases besides $\mathrm{CD}^{(3,9)}$. The histopathologic characteristics of this child biopsied sample were compatible with $\mathrm{CD}$ but, as previously cited, biopsy can be misleading in these children as very similar patterns can be seen in children with severe malnutrition and repetitive infections of the gastrointestinal tract. Figure 1 shows the similarity between this child's biopsy sample (A) and the biopsy sample of a non-celiac child suffering from repetitive gastrointestinal infections and severe malnutrition (B).

The fact that his recovery was extremely slow even after the institution of a strict GFD reinforced our doubts concerning the diagnosis. After the gluten challenge a positive result was obtained on this child's previously negative IgA-EMA test. It is a fact that around $20 \%$ of infants, mainly below the age of 2-years yield false negative results on EMA testing ${ }^{(4)}$. 


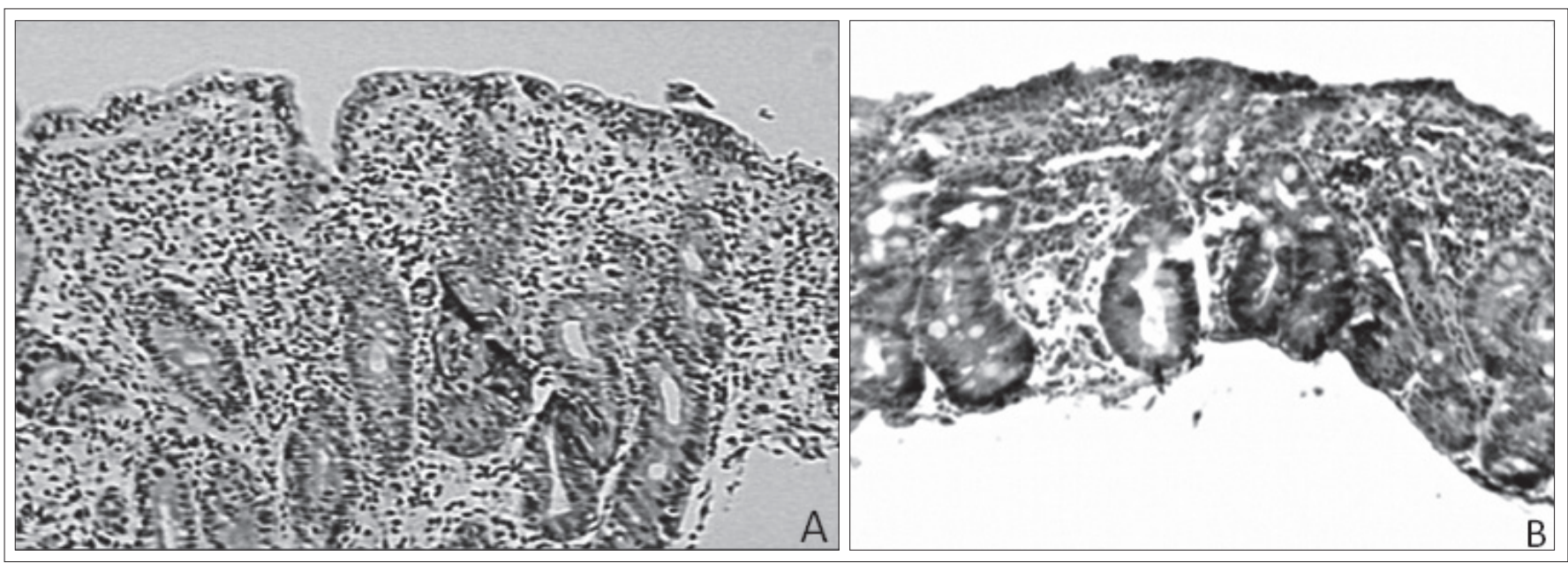

FIGURE 1. (A) Jejunal biopsy of patient no. 5, showing villous atrophy, crypta hyperplasia and increased number of intraepithelial lymphocytes (>40/100); (B) Jejunal biopsy of a IgA-tTG and IgA-EMA negative non-celiac patient, with infeccious diarrhea caused by enteropatogenic $E$. coli 0111 showing a total villous atrophy, cript hyperplasia and increased number of intraepithelial lymphocytes $(>40 / 100)$

As showed in other studies, the low specificity of the AGA test could once again been observed. This reinforces the fact that currently, due to the existence of the more reliable recombinant human $\mathrm{tTG}$ and antiendomisyum tests the AGA test is only justifiable in those cases in which the patient reveals an absolute deficiency of IgA.

In conclusion, in the present study a prevalence of $2.3 \%$ was found among symptomatic 12 - to 36 -month-old children that had not been previously diagnosed as celiac. This finding reinforce the need of a careful investigation of children belonging to low socio-economic strata and living in adverse environmental condition since CD symptomatology, in this group of children, can be easily masked by the frequently observed environmental enteropathy that is also characterized by malnutrition, failure to thrive and persistent diarrhea.

Modelli IC, Gandolfi L, Almeida RC, Araújo GMAC, Picanço MA, Pratesi R. Rastreamento sorológico da doença celíaca em crianças sintomáticas com 12 a 36 meses de idade. Arq Gastroenterol. 2010;47(1):61-5.

RESUMO - Contexto - O diagnóstico correto da doença celíaca em crianças ambientalmente carentes é frequentemente dificultado pela presença usual de causas outras para os clássicos sintomas da doença celíaca. Objetivo - Determinar a prevalência de doença celíaca em um grupo de crianças com idades compreendidas entre 12 e 36 meses, utilizando a pesquisa de anticorpos antigliadina (IgG e IgA-AGA), antiendomísio (IgA-EMA) e antitransglutaminase recombinante humana (IgA-tTG) como método de rastreio. Métodos - Foram incluídas no estudo 214 crianças (114 meninos), com 12 a 36 meses de idade, todas em uso de dieta contendo glúten. Em todos os soros foi pesquisada a presença de anticorpos anti-IgG e IgA-AGA, anti-IgA-EMA e anti-IgA-tTG humana. Biopsia jejunal foi sugerida e efetuada em todas as crianças com resultados positivos em um ou mais testes sorológicos, excetuando-se as crianças em que o IgG-AGA tinha sido o único teste positivo. Nesta última situação, efetuou-se genotipagem para identificação de possíveis alelos HLA predisponentes por meio do método de PCR. Para confirmação do diagnóstico, a genotipagem dos alelos HLA também foi efetuada nas crianças identificadas como celíacas com base a testes sorológicos positivos e resultado da biopsia jejunal compatível. Resultados - Em 131 crianças os resultados dos testes sorológicos foram normais. Em 68 delas, foi detectada apenas a presença de anticorpos anti-IgG-AGA. Em 10 destas, por terem apresentado presença de alelos HLA predisponentes, foi realizada biopsia jejunal, que revelou mucosa sem alterações. Todos os testes sorológicos foram positivos em quatro crianças. Os testes igG e IgA-AGA e IgA-tTG foram positivos numa quinta criança que, no entanto, apresentou teste IgA-EMA negativo. A biopsia jejunal dessas cinco crianças revelou lesões de mucosa típicas e compatíveis com o diagnóstico de doença celíaca. Conclusão - Prevalência de 2,3\% foi encontrada entre crianças de 12 a 36 meses de idade, não previamente diagnosticadas como celíacas.

DESCRITORES - Doença celíaca, diagnóstico. Testes sorológicos. Criança. 


\section{REFERENCES}

1. Akobeng AK, Ramanan AV, Buchan I, Heller RF. Effect of breast-feeding on risk of celiac disease: a systematic review and meta-analysis of observational studies. Arch Dis Child. 2006;91:39-43.

2. Ascher H, Holm K, Kristiansson B, Mäki M. Different features of coeliac disease in two neighbouring countries. Arch Dis Child. 1993;69:375-80.

3. Bizzaro N, Villalta D, Tonutti E, Doria A, Tampoia M, Bassetti D, Tozzoli R. IgA and IgG tissue transglutaminase antibody prevalence and clinical significance in connective tissue diseases, inflammatory bowel disease, and primary biliary cirrhosis. Dig Dis Sci. 2003;48:2360-5.

4. Bürgin-Wolff A, Gaze H, Hadziselimovic F, H Huber, M J Lentze, D Nusslé, Reymond-Berthet C. Antigliadin and antiendomysium antibody determination for coeliac disease. Arch Dis Child. 1991;66:941-7.

5. Carlsson A, Axelsson I, Borulf S, Bredberg AC, Ivarsson SA. Serological screening for celiac disease in healthy 2.5 -year-old children in Sweden. Pediatrics. 2001;107:42-5.

6. Catassi C, Rätsch IM, Fabiani E, Ricci S, Bordicchia F, Pierdomenico R, Giorgi PL High prevalence of undiagnosed coeliac disease in 5280 Italian students screened by antigliadin antibodies. Acta Paediatr. 1995;84:672-6.

7. Cerf-Bensussan N, Cellier C, Heyman M, Brousse N, Schmitz J. Coeliac disease: an update on facts and questions based on the 10th International Symposium on Coeliac Disease. J Pediatr Gastroenterol Nutr. 2003;37:412-21.

8. Chaves RG, Lamounier JA, Cesar CC. Factors associated with duration of breastfeeding. J Pediatr (Rio J). 2007;83:241-6.

9. Clemente MG, Musu MP, Frau F, Lucia C, De Virgiliis S. Antitissue transglutaminase antibodies outside celiac disease. J Pediatr Gastroenterol Nutr. 2002;34:31-4

10. Corazza GR, Andreani ML, Biagi F, Corrao G, Pretolani S, Giulianelli G, Ghironz G, Gasbarrini G. The smaller size of the "coeliac iceberg" in adults. Scand J Gastroenterol. 1997;32:917-9.

11. Crovella S, Brandão L, Guimarães R, Crovella S, Ventura A. Speeding up coeliac disease diagnosis in developing countries. Dig Liver Dis. 2007;39:900-2.

12. Gandolfi L, Pratesi R, Cordoba JC, Tauil PL, Gasparin M, Catassi C. Prevalence of celiac disease among blood donors in Brazil. Am J Gastroenterol. 2000;95: 689-92.

13. Gandolfi L, Catassi C, Garcia S, Modelli IC, Campos D Jr, Pratesi R. Antiendomysial antibody test reliability in children with frequent diarrhea and malnutrition: is it celiac disease? J Pediatr Gastroenterol Nutr. 2001;33:483-7.

14. Green PHR, Jabri B. Celiac disease. Annu Rev Med. 2006;57:207-21.

15. Hadithi M, von Blomberg BM, Crusius JB, Bloemena E, Kostense PJ, Meijer JW, Mulder CJ, Stehouwer CD, Peña AS. Accuracy of serologic tests and HLA-DQ typing for diagnosing celiac disease. Ann Intern Med. 2007;147:294-302.

16. Hardwick C. Prognosis in celiac disease. A review of seventy-three cases. Arch Dis Child. 1939;14:279-93.

17. Hoffenberg EJ, Mackenzie T, Barriga KJ, Eisenbarth GS, Bao F, Haas JE, Erlich H, Bugawan Tl T, Sokol RJ, Taki I, Norris JM, Rewers M. A prospective study of the incidence of childhood celiac disease. J Pediatr. 2003;143:308-14.

18. Ivarsson A, Hernell O, Stenlund $\mathrm{H}$, Persson LA. Breast-feeding protects against celiac disease. Am J Clin Nutr. 2002;75:914-21.

19. Karell K, Louka AS, Moodie SJ, Ascher H, Clot F, Greco L, Ciclitira PJ, Sollid LM, Partanen J; European Genetics Cluster on Celiac Disease. HLA types in celiac disease patients not carrying the $D Q A 1 * 05-D Q B 1 * 02$ (DQ2) heterodimer: results from the European Genetics Cluster on Celiac Disease. Hum Immunol. 2003;64:469-77.

20. Mäki M, Mustalahti K, Kokkonen J, Kulmala P, Haapalahti M, Karttunen T, Ilonen J, Laurila K, Dahlbom I, Hansson T, Höpfl P, Knip M. Prevalence of celiac disease among children in Finland. N Engl J Med. 2003;348 2517-24.

21. Marsh M. Gluten, major histocompatibility complex, and the small intestine Gastroenterology. 1992;102:330-54

22. Melo SB, Fernandes MI, Peres LC, Troncon LE, Galvão LC. Prevalence and demographic characteristics of celiac disease among blood donors in Ribeirão Preto, State of São Paulo, Brazil. Dig Dis Sci. 2006;51:1020-5.

23. Oliveira RP, Sdepanian VL, Barreto JA, Cortez AJ, Carvalho FO, Bordin JO, de Camargo Soares MA, da Silva Patrício FR, Kawakami E, de Morais MB, FagundesNeto U. High prevalence of celiac disease in Brazilian blood donor volunteer based on screening by IgA antitissue transglutaminase. Eur J Gastroenterol Hepatol. 2007;19:43-9.

24. Pereira MA, Ortiz-Agostinho CL, Nishitokukado I, Sato MN, Damião AO, Alencar ML, Abrantes-Lemos CP, Cançado EL, de Brito T, Ioshii SO, Valarin SB, Sipahi AM. Prevalence of celiac disease in an urban area of Brazil with predominantly European ancestry. World J Gastroenterol. 2006;12:6546-50.

25. Peters U, Schneeweiss S, Trautwein EA, Erbersdobler HF. A case-control study of the effect of infant feeding on celiac disease. Ann Nutr Metab. 2001;45: 135-42.

26. Pratesi R, Gandolfi L, Garcia SG, Modelli IC, Lopes de Almeida P, Bocca AL, Catassi C. Prevalence of celiac disease: unexplained age-related variation in the same population. Scand J Gastroenterol. 2003;38:747-50.

27. Sacchetti L, Tinto N, Calcagno G, Improta P, Salvatore F. Multiplex PCR typing of three most frequent HLA alleles in celiac disease. Clin Chim Acta. 2001;310;205-7.

28. Sena MCF, Silva EF, Pereira MG. Prevalence of breastfeeding in Brazilian capital cities. Rev Assoc Med Bras. 2007:53:520-4.

29. Simell S, Hoppu S, Hekkala A Simell T, Ståhlberg MR, Viander M, Yrjänäinen H, Grönlund J, Markula P, Simell V, Knip M, Ilonen J, Hyöty H, Simell O. Fate of five celiac disease-associated antibodies during normal diet in genetically atrisk children observed from birth in a natural history study. Am J Gastroenterol. 2007;102:2026-35.

30. Simell S, Kupila A, Hoppu S, Hekkala A, Simell T, Ståhlberg MR, Viander M, Hurme T, Knip M, Ilonen J, Hyöty H, Simell O. Natural history of transglutaminase autoantibodies and mucosal changes in children carrying HLA-conferred celiac disease susceptibility. Scand J Gastroenterol. 2005;40:1182-91.

31. Sollid LM. Coeliac disease: dissecting a complex inflammatory disorder. Nat Rev Immunol. 2002;2:647-55.

32. Trevisol C, Brandt KG, Pontes Silva GA, Crovella S, Ventura A. High prevalence of unrecognized celiac disease in an unselected hospital population in NorthEastern Brazil (Recife-Pernambuco). J Pediatr Gastroenterol Nutr. 2004;39: 214-5.

33. Uibo O, Metskula K, Kukk T, Rägo T, Uibo R. Results of coeliac disease screening in Estonia in 1990-1994. Acta Paediatr Suppl. 1996;412:39-41.

Received 17/4/2009.

Accepted 7/7/2009. 